Primljen / Received: 12.9.2013.

Ispravljen / Corrected: 27.12.2013.

Prihvaćen / Accepted: 17.1.2014.

Dostupno online / Available online: 10.3.2014.

\section{Evaluation methods in the protection of built heritage}

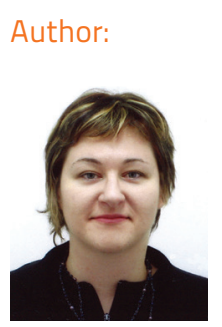

Iva Mrak, PhD. Arch.

University of Rijeka

Faculty of Civil Engineering

iva.mrak@gradri.uniri.hr
Iva Mrak

\section{Evaluation methods in the protection of built heritage}

The growth of built heritage, and an increasing public interest for its conservation, combined with depletion of public resources, has lead to the development of the field of heritage management. This field includes cultural and economic understanding of heritage, valorisation of heritage, integral approach to spatial planning, participation of public in the decision-making process, and development of rational and transparent decision-making mechanisms. Decision-aid tools have a specific and highly significant role in this process. The development of evaluation methods is described, and possible uses of various evaluation models in the field of heritage are analysed in the paper. Key words:

evaluation methods, cultural built heritage, multicriteria analysis

Pregledni rad

Iva Mrak

\section{Metode procjene u funkciji očuvanja graditeljske baštine}

Povećanjem baštine i jačanjem interesa javnosti za očuvanjem baštine te smanjenjem javnih resursa, pojavljuje se potreba za razvojem polja upravljanja baštinom. Ovo polje uključuje kulturološko i ekonomsko shvaćanje baštine, valorizaciju baštine, integralni pristup prostornom planiranju, sudjelovanje javnosti u procesima odlučivanja i razvoj racionalnog i transparentnog odlučivanja. U tom procesu, posebno su važni alati pomoći pri odlučivanju (eng. decision-aid tools). U članku se opisuje razvoj metoda procjena i analizira mogućnost primjene različitih modela procjena u području baštine.

Ključne riječi:

metode procjene, kulturna graditeljska baština/naslijede, višekriterijska analiza

Übersichtsarbeit

Iva Mrak

\section{Bewertungsverfahren im Schutz von Baudenkmälern}

Der Wachstum des baulichen Erbes und das zunehmende öffentliche Interesse für seine Erhaltung haben im Einklang mit der Reduzierung öffentlicher Mittel zur Entwicklung der Denkmalsverwaltung geführt. Dieser Bereich umfasst das kulturelle und wirtschaftliche Verständnis des Kulturerbes, sowie seine Valorisierung, einen umfassenden Ansatz zur Raumplanung, die Öffentlichkeitsbeteiligung an Entscheidungsfindungen und die Entwicklung von rationellen und transparenten Entscheidungsmechanismen. Entscheidungshilfsmittel haben eine wichtige Rolle in diesem Prozess. In dieser Arbeit ist die Entwicklung von Bewertungsverfahren beschrieben und ihre Einsatzmöglichkeiten im Bereich des Kulturerbes analysiert. 


\section{Introduction}

Different evaluation methods, including multicriteria evaluations, are normally encountered and used as decision-aid tools in various human activities, from decision-making in big companies and in the sphere of spatial planning to the decisions we make in our personal life.

Some forms of evaluation are based on monetary value, while others are a combination of qualitative and quantitative evaluations that can only partly be expressed in monetary terms. In such cases, use is made of multicriteria evaluations, involving both quantitative and qualitative criteria. The multicriteria type of evaluation is especially advantageous in the analysis of values that can not be reduced to monetary value, such as the historical value, value of personal choice, cultural value, social significance, etc. This is why the use of multicriteria evaluation is increasingly encountered in disciplines dealing with culture or society, such as in management of cultural assets, and in the sphere of spatial planning.

The cultural built heritage is a highly specific area marked by cultural aspects, engineering and architectural features, and by its presence in space. Cultural aspects of the built heritage may include the artistic aspect, historical aspect (involving both general history and art history), spiritual aspect, and also the social aspect showing how the cultural aspects influence the society. Civil engineering and architectural features are related to the engineering approach and solution to a given problem, from defining the initial concept, use of a selected scientific model, solution-defining method, technical solution, and form shaping. The spatial presence of heritage denotes interaction with the local and global population through economic processes, but also through the influence on the identity of the population or a population group [1-3].

The distinctive feature of the cultural built heritage, compared to other types of cultural heritage, is that it creates the space in which people spend their time or live, and is therefore an inevitable part of human life. As such, it influences people's self-perception, and also the production and economic processes $[2,4,5]$.

This is why evaluation methods consider heritage from different aspects and in relation to different objectives - identification and definition of cultural value of heritage, definition of its social value, economic value, use value, etc.

Evaluations can also be made in different time intervals: during strategic decision-making, when making decisions on possible realization of a project, when deciding on social sustainability of a project or development plan, and in the scope of monitoring or analysis of development possibilities. For instance, evaluations are used during definition of contracts, in the scope of various arrangements, municipal contracts, public participation opportunities, financing and micro-crediting, and also in tax policy, discussions, and investigations, and this at the strategic, tactical and management levels [6].

Someevaluation methods that areused in thesphereof heritageare general evaluation methods, methods that have been developed for other disciplines (e.g. for company management), or methods developed specifically for definition of heritage characteristics. It can generally be argued that evaluations are increasingly used in decision making due to obligatory assessment of the impacts of projects, plans and programs on the human environment and nature. The development of evaluation methods is influenced by the development of the discipline of heritage management because of the increasing quantity of heritage assets and the decrease in resources (e.g., when deciding on the use of funds for the protection of banking and corporate foundations, but also for the management of EU funds).

\section{Role of evaluation methods in the cultural heritage management and in sustainable development of space}

Management of spatial development comprises analyzing and orienting the change of physical and social characteristics (e.g. through preparation of spatial plans), and also the decisionmaking process itself [7]. Decision-making processes are an integral part of the space management process, and may significantly influence the quality and sustainability of strategies, and proper implementation of spatial plans. If a decision-making process is not based on the extant (including social characteristics) and on consultation of public opinion, then the planning process is likely to result in a plan that is not the result of spatial properties, and that is contrary to the needs of the population. That is why multidisciplinary analyses and public participation processes are increasingly being integrated into the planning and strategic decision-making processes, which is compliant with appropriate European directives [8] and Croatian legislation.

The public participation process should start in strategic phases during which common goals and values are defined, and in the course of which various proposals can be formulated. In these phases, various public participation techniques, oriented to smaller or greater stakeholder groups, can be useful: future search, planning for real, citizen juries, e-forums, etc. Each of these techniques is appropriate for one or several situations, and they also may be combined as appropriate [9-12].

Stakeholders are oftentimes in conflict with each other, or they may change their reference values over time, and the objective of one group often influences objectives of other groups, and so it may be stated that criteria and their weights are dependent on time and space. This is why methods for solving inter-group conflicts through mediation, negotiations, and trials are highly significant [12]. Any lack of clarity during the planning and evaluation processes may result in sub-optimisation, i.e. something that may have a positive impact in one aspect may prove to be negative in another aspect, or from a general standpoint [13]. Proper selection of an evaluation method in the identification and resolution of conflicts may be very helpful, but it is important that the method enables analysis of impacts in relation to different social sectors [14]. If evaluation is to be used in compliance with modern management principles and regulations, then such evaluation must be rational, logical and 
coherent, and should also be flexible so that it can be used - easily and transparently - in different decision making contexts. Vested with such properties, evaluation methods may appropriately be used in the management of complex quantitative, qualitative, and often unreliable data.

Characteristics of evaluation models are dependent on the situation, availability of data, complexity, and available time, but also on the level and the objective of the decision (strategic or implemental decision-making level) [15]. That is why characteristics such as modularity, understandability, clarity and flexibility [16] are important for an efficient use of evaluation methods.

During the processes conducted to find solutions (technological, civil engineering, planning, etc.), appropriate alternatives are prepared and are compared to one another in order to find the alternative that meets the required criteria. In spatial planning, alternatives are expressed through preparation of alternative scenarios representing space in a more distant future. Indicators that describe a scenario must express complexity of space showing identity features, differences, morphologies, typologies, public spaces, architectural perceptions, social and functional differences, and a balance between the role of public administration and private sector [17]. Indicators should also reflect the structure of social values, as it is only the acceptance of process values that will lead to acceptance of process results [18].

A valuable evaluation is a procedure that "enables determination of the priority list of alternatives by means of arguments" [19], contributes to improvement of procedural rationality and process quality, assists in forming new alternatives, encourages participation of various social sectors, and enables control during implementation of the selected alternative.

For instance, Voogd [14] presents characteristics of a good evaluation method: adequacy (the method creates information that is helpful In decision making), credibility (the method is logically coherent, i.e. care is taken about measures or the sign of an influence), usability (the method can be used with available resources and in the given time frame), acceptability (the method is clearly understandable to decision-makers and planners, but also to the public; the method is transparent and its validity has already been proven).

The evolution of perception of heritage conservation as a part of sustainable spatial development, and of an integral approach to built heritage that has been developing since the mid twentieth century, has lead to the current perception of contemporary space which is regarded as a multi-layered complex system characterized by signs, elements, and nonmaterial relationships $[20,21]$. The understanding of the role of built heritage in sustainable development has become crucial for maintaining continuity in spatial change and development of new activities, especially in the conflict between competitive international growth and sustainable local strategies [22]. The importance of selecting an appropriate use of the heritage has also been the theme of numerous international documents.

The new use of the heritage has to respect the balance between the need for new activities and the preservation of existing qualities. As each preservation activity thus becomes an activity in the creation of spatial and societal relationships, an increasing significance in the heritage preservation process is given to the integration of methods for evaluation of cultural and societal values into the very space planning process [3].

Evaluation tools are significant components of the decision-aid tools used in decision making processes. Evaluation tools can help in determining: existing situation in physical space (analysis), determination of objectives, gap between the existing situation and objectives (diagnosis), strategies for reaching the objectives, evaluation of alternatives and monitoring.

Although representing a simplified reality, scientific models should not be devoid of significant aspects of reality. Evaluation models aimed at estimating complex relationships and multilayered interactions must be based, just like in management of cultural built heritage, on understanding of the concepts of sustainable development, cultural assets, and physical space. As creation of heritage is a social product, i.e. a fluid social and political process [1, 23], the analysis and evaluation of heritage must reflect its complexity. Evaluations help in understanding underlying opportunities and external effects (private and public), management methods, and influence exerted by legislation [24].

\section{Development of evaluation methods}

\subsection{Methods for evaluation of values expressed in monetary terms}

Evaluation methods, such as the cost-benefit analysis, are used to evaluate values that can directly be expressed in monetary terms, but also those that can not be directly be expressed in monetary terms, through their market value. Values expressible in money comprise a whole array of values, from those that are relatively easy to determine (e.g. market value or exchange value, client's earnings, purchase costs, etc.) to those that are more difficult to estimate (e.g. a multiplying effect of an investment). However, the evaluation of non-monetary values calls for additional indirect methods, i.e. for contingent evaluation methods [4, 25-27].

In mid 1950s, Marion Clawson and Jack L. Knetsch developed the Travel Cost Method (TCM) whose main distinguishing feature is that it does not evaluate the cost of an item (e.g. environment) directly, but it concentrates on secondary costs such as the principal and secondary costs of travel that the users of an item (e.g. environment) are willing to pay (as established form real spending). The result is the sum of costs that is equal to the lowest value of the item that is evaluated. This method does not determine the total value but informs us that something is worth "not less than" the amount corresponding to the sum of the costs considered in the analysis. When forming the sum, the method uses precisely defined questionnaires, statistical evaluation, and a long evaluation period of, for instance, twenty years [4].

The Willingness to Pay (WTP) and the Willingness to Accept (WTA) methods are contingent evaluation methods that are used to estimate the value of an item through expression of 
the willingness to pay for such item (e.g., preservation of a monument), or willingness to accept a payment so as to accept the loss of such an item (e.g. monument). These values are expressed through responses given in a survey, rather than through actual incurred costs. It is typical for this type of evaluations to depend on the financial situation of respondents, and on whether the question is put as a willingness to pay or willingness to accept, where the willingness to accept results in a higher rating due to the renunciation effect which is rated higher than the effect of gain $[25,27]$. This method has, for instance, been used when estimating costs and benefits of renewal of the historic core of the town of Split, in the World Bank study prepared in late 1990s [28, 29].

In the Value for Money (VFM) method real costs are compared with subjective satisfaction. The downside of the method is that it is very difficult to define which costs can be included in the costs of the use of a facility (e.g. visit to archaeological site includes costs of travel or entrance fee only, etc.) [4].

In the Hedonic price method (HPM), the statistic regression method is used to verify the influence of an individual characteristic (e.g. cultural aspect) on the total price of an item/facility. This method requires knowledge of real prices and is normally used in the economics of real estate, but it also does not express the total value of a characteristic, but rather the value relating to the use of a real estate item [27].

These methods served as basis for development of other methods such as the Replacement Value method, Repeated Production method, etc. Some authors criticize the use of monetary evaluation methods for goods with the pronounced non-market value, such as cultural goods. Usually, the basic reason is the complexity of determining the value of such assets, but also the impossibility of conducting accurate evaluation by means of such methods $[2,4$, 30-32]. On the other hand, Fusco Girard and Nijkamp [15] consider that low-income groups and future generations are not able to express their opinion through monetary evaluations.

The value of cultural heritage is a complex value that is composed of the direct use value, indirect use value, option value, existence value, and cultural legacy value [15]. According to Throsby [21], the cultural value is a multi-dimensionally complex value and it contains: aesthetic, spiritual, social, historical, symbolic value and the authenticity value. Fusco Girard and Nijkamp [15] define the Complex Social Value (Valore Sociale Complesso) as the complex value that reflects the dynamic relationship between the use and other values of cultural heritage items (non-repeatability, authenticity, psychological and social values, etc.) that contribute to the stability of human eco-systems (preservation of identity, unity, social stability, development, etc.).

Determination of these complex values requires evaluation methods that are able to express both quantitative and qualitative characteristics of heritage, and to do so in a way that enables evaluation of individual aspects as well as an overall evaluation. Because of these requirements, decision-making processes relating to heritage increasingly rely on multicriteria methods, as they are able to take into account different and highly varied aspects of such heritage.

\subsection{Methods for evaluating values in non-monetary terms}

Knowledge models, and hence the analysis and evaluation models, are based on the observation of sets. During this observation, individual set elements, as well entire sets, are subjected to analysis. Representation of reality by means of models enables rational examination of complex information systems and this by reducing the complexity of the problem [33].

Initial bases of multicriteria evaluations can be found in the Pareto efficiency concept (Pareto optimum in the distribution of resources is obtained when the situation of one subject can not be improved without worsening the situation of the other subject) in which a non-dominated alternative is sought $[15,34]$. This principle is the basis of most modern hierarchyanalysis methods.

By development of value-focused thinking [35], which is the link between creative thinking and structured decision making, the evaluation has enabled identification of decisionmaking opportunities instead of the mere evaluation of existing alternatives. Thus, evaluation models can be used to determine the current condition of an object, but also its distance from an ideal condition (making a diagnosis), and can also compare alternatives with respect to individual criteria (analysis of alternatives). This way of understanding the role of evaluation is of crucial significance as it enables conduct of an interactive process during which new alternatives closer to the desired situation - are created, instead of simply deciding between two (or more) alternatives, all of which may be unsatisfactory $[15,34]$.

Figure 1 shows in a synthetic way how alternatives and ideal points move based on value-focused thinking and communication. Initially, a selection can be made between given alternatives (zone of compromise between given alternatives). At this point not a single one fully meets the required criteria, although some of them may in some aspects even exceed initial expectations. After evaluation (in the sense of analysis and diagnosis) and communication, a new ideal point marked by somewhat higher requirements may be identified. The zone between the existing alternatives and an ideal point is then created (zone of creative alternatives after evaluation) in which new alternatives necessitating consideration desired values are sought. Alternatives formed in this way meet higher criteria when compared to initial alternatives. Value-focused thinking helps not only in forming new alternatives, but also in the identification of hidden motives and significant indicators. Foundations can thus be created for communication with nontechnical groups, conflicts can be avoided, and positive-sum strategies can be formed instead of zero-sum strategies [15]. In this way, evaluation methods become valuable instruments of rational planning [14].

Unfortunately, evaluations are oftentimes used (if used at all) in the last step of decision-making, when alternatives and 
their characteristics have already been fully defined and when only measures for moderating unfavourable characteristics can be proposed, because substantial improvements can not be made at this final stage. The reason behind the use of such inadequate practices most often lies in the dynamics and steps applied in bureaucratic procedures, and in restrictive nature of decision-making processes which are closed or inaccessible to non-institutional stakeholders such as the general public [14].

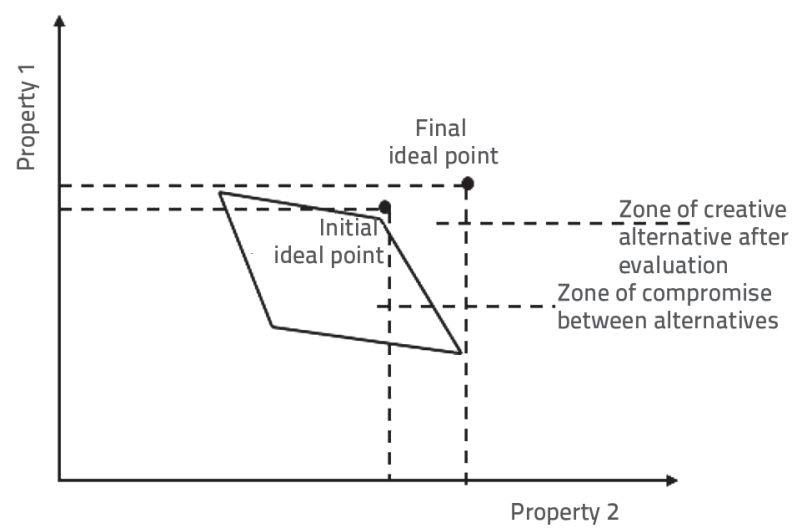

Figure 1. Change of ideal point during the decision making process synthesized presentation according to [34]

Taking into account the above mentioned situation, Zeleny [34] identifies three ways in which alternatives can be created: creation or introduction of a new strategy, change of strategy to achieve a new goal, and formation or introduction of new goals or criteria. The evaluation of alternatives implies at least two mutually exclusive alternatives, and their creation has to be continued until possibilities for creating different alternatives are fully exhausted. It is important to check whether alternatives are coherent with presented values, and it is especially significant to analyse alternatives that are not evident at first glance.

\subsection{Evaluation of social value in space planning and public participation}

The first known example of multicriteria evaluation is Benjamin Franklin's letter to his friend Joseph Priestley, written in 1772. In this letter, he describes his Moral or Prudential Algebra which is based on presentation of positive and negative aspects and different weights of a decision.

In the twentieth century, various forms of multicriteria analyses (MCA) were developed through complex decision-making procedures in the scope of organisation of military operation or big companies. Although some know mathematicians considered conflict problems soon after the Second World War (e.g. John von Neumann and Oskar Morgenstern), multicriteria analyses were mostly considered by engineers working in big companies, and this primarily from the aspect of computer programming. As of 1970s multicriteria analyses have also be used in other areas that require making decisions in complex contexts, such as spatial planning [34]. Probably the most important evaluation model, which has become the basis for most of subsequently developed models, is the Leopold matrix model described in 1971 [36]. This model is based on multicriteria matrix in which planned interventions and environmental components are presented. Thus the data about the intervention and environment are introduced into the matrix, and significant impacts, positive and negative signs, evaluations, and weights, are marked.

It has been established that the matrix evaluation method is especially favourable for the detailed determination of environmental impact, in both the scope of assessment of environmental impacts of projects, and the strategic evaluation of the impacts various plans and programs have on the environment and nature, as the method enables structured verification of a wide array of impacts exerted on ecosystems [8].

By acceptance of European directives, environmental impact evaluations have also become obligatory in Croatian legislation. The European approach is marked by bureaucratic and technocratic nature of the evaluation process (the evaluation is normally conducted by public administration, and the voice of general public is accepted only in the smallest legally accepted proportion), while the American approach is more oriented toward communication with the general public. The idea of "impact" implies unidirectional effect of a project on the environment, and not the converse, which points to the separate nature of the design and evaluation processes. Evaluation should be made in initial phases so that various alternatives can be created in the design process [37].

Currently, a special emphasis is placed on mathematical methods for determination of hierarchical priorities. These methods have been introduced in the area of project management, and hence also in the area of planning, from the context of big companies. Based on stated preferences and mathematically complex methods, these methods determine an appropriate priority scale. Some of the methods are: Saaty's Analytic Hierarchy Process (AHP) and Analytic Network Process (ANP), Zeleny's theories, Regime Analysis by Nijkamp and Hinloopen, Rough Set Analysis, Evamix method, Vimda method [15], etc. The use of these methods is often facilitated by readily-available software tools (PrometheeGaia software, University of Bruxelles, Definite software, University of Amsterdam, Electre Tri, Rankrit, Micro-Qualiflex, etc.), or the tools can be programmed depending on the method that has been selected. These tools provide highly summarized results but, because of such condensed data, it is difficult to use them in discussions with stakeholders.

Over the past several years, the use is also made of tools based on the geographic information system, or GIS tools, where the spatial distribution of impacts can efficiently be presented, while critical portions of space can also be determined in the analysis phase. This way of spatial distribution analysis directly relies on the Mc Harg analysis by the Map-overlay technique which, until recently, had to be conducted manually. The use of GIS tools in combination with satellite surveying, and with prediction models based on cellular automata, is also significant for the creation of alternative scenarios [22]. 
The Community Impact Evaluation (CIE) [38], proposed by Lichfield and characterised by analysis of distribution of impacts among social sectors, has been increasingly used in recent years. This method identifies goals of each sector, defines impacts on each sector based on the predefined goal, and determines probability and significance of impacts. The analysis concentrates on various social sectors (land owners in construction area, other land owners, investors, local self-rule, state, users, etc.), types of project impacts on individual sectors (increase in land value, higher tax income, creation of new urban values, etc.), and on the type of data needed for evaluation (monetary and non-monetary values). The model synthesizes different evaluations (financial, social, environmental) and efficiently shows distribution of influences of individual proposals on various social sectors. The determination of costs and benefits by social sectors enables planning of project compensations and improvements. This method has been developed for conducting evaluations in complex situations, such as in urban environments with the presence of various sectors and with complex aspects of the project or plan.

In addition to these methods, some simpler methods are very often used as the first approach to problems. They enable simple and fast description of the decision-making problem (scenario) based on a small amount of data. These methods include SWOT analysis, cobweb diagram (or spider model), flag model, and similar models.

The SWOT analysis (where SWOT stands for: strengths, weaknesses, opportunities, threats) is one of the best known analyses that are used in a wide array of contexts. It enables analysis of development of a facility both for the present time and in the future. This analysis has inter alia been used in the Program of Sustainable Development for the islands of Krk, Rab, Sv. Grgur, Goli, and Dolin, prepared by the Physical Space Planning Department of the Primorje-Gorski Kotar County.

The cobweb method $[15,39]$ is a graphic presentation of scenarios which enables an efficient and clear comparison of scenarios based on previously selected criteria. The method is efficient for communication with the public in the first phases of the decisionmaking process. A very similar method is the flag method in which data are presented in form of bands that describe scenarios according to predefined criteria. It also enables simple presentation of the distance from the target value.

The choice of evaluation method depends on the context, but also on the planned objective of the evaluation [40]. The "panoramic" methods that structure the information have been proven in practice as more adequate than the mathematically more complex hierarchical definition methods, although the latter method are also often in use.

\section{Methods for evaluation of cultural heritage}

As heritage is a social product $[1,23,41]$, the analysis and evaluation of heritage must express the complexity of analysed elements. The objectives of economic and social sustainability in the management of heritage are manifested as analyses of the effects on population, externalities on various social sectors, and on the definition of the heritage management objective.
In examples of space with a pronounced presence of heritage, analyses comprise geological, biological, morphological and landscape properties. Analyses often focus on historicalmorphological changes of spatial characteristics in order to avoid excessive simplification in the presentation of space, which is typical for modern space planning. In fact, modern space planning (since the introduction of zoning) treats space as an Euclidean pure space [21] (monocultural or post-Fordean conception of space [42]).

The multicriteria evaluation models contain evaluations from different disciplines, and these evaluations should preferably be articulated as special modules. The evaluation of heritage requires special analyses and techniques, e.g. relating to architecture or landscape and, in these models, the aspects of analysis and evaluation can not often be differentiated from one another.

The models for evaluation of individual elements of built heritage consider a single element (or a complex), while evaluations focusing on landscape comprise all significant characteristics of landscape (hydrological systems, space enclosing elements, trees, animals, etc.). Thus landscape evaluation models analyse various features of heritage: obsolescence, duration, scarcity, artistic creativity, connection with historic persons or events, recognition, registration, conservation, interpretation, loss, and passage of time [43].

Kalman's method $[40,44]$ is based on the prepared table with indicators and sub-indicators, which are attributed appropriate values in accordance with a predefined scale. These indicators are: architecture (with sub-indicators: style, construction, age, architect, design, interior), history (with sub-indicators: person, event, context), environment (with sub-indicators: continuity, setting, landmark), usability (with sub-indicators: compatibility, adaptability, public, services, cost), integrity (with sub-indicators: site, alterations, condition). The same cards can be used for the analysis of the extant, for evaluation of the designed state (including comparison with other projects), and for monitoring. This method has been developed for the evaluation of architecture, and is hence less adequate for the evaluation of open spaces.

Campeol's pyramidal model was developed during the work on the UNESCO project Urban Development and Freshwater Resources: Small Coastal Cities [45] and, in Croatia, the model was used on examples of Omišalj municipality and Rječina park for the City of Rijeka. The model is based on multicriteria analysis where data about space are grouped according to "qualities" and "damage" within the matrix model, and then the type of project is defined conservation, valorisation, preservation, renewal, regulated use, new use. This model enables synthetic approach to the issue of heritage. Lichfield defines the approach called "heritage value for money" [38], which is based on the analysis of costs and benefits. Project effects and efficiency are identified and priority activities are defined taking into account the budget allocated for the project. The method is used to analyse distribution of benefits and costs throughout the life cycle of a structure/facility, discount rate, loan costs and distribution of impacts on social sectors. The method comprises data about individual cultural assets and is especially efficient when used with other types of evaluations that estimate features of heritage. 
The model involving the entrepreneur approach [46] briefly describes activities that can be made with respect to heritage, taking into account the existing resources. This approach makes use of a table organised in fields such as cost (small, medium, and high cost) and type of intervention (maintenance, renewal, and change of use). For each combination of resources and intervention type, the approach gives indications about possible interventions (valorisation, maintenance, forming minimum conditions for subsequent interventions, change of use for innovative initiatives, etc.). Although the characteristic part of the evaluation is synthetic, in a part of the analysis this model checks different financial resources, social needs, results of services, market and context, management methods, financial sustainability both in the initial phase and during use. The model is based on economic analysis, but is specially adjusted to heritage evaluation.

The landscape evaluation method is developed by Canadian national parks (Parks Canada) [47]. As Kalman is the (co-) author of this method as well, it is not surprising that it is very similar to the method for evaluation of architectural heritage. Indicators (and sub-indicators) are a historical association (with the theme, people/events, local development), architecture (aesthetic design - proportions, scale, details; functional design - materials, availability, building methods; artisanship and materials; architect - representativeness), environment (site - integrity, relation of building to landscape; context - influence of the building on the area; monument nature of the building and the community). Each sub-indicator is allocated one of the predefined ratings.

The model for evaluation of archaeological impact developed by Campeol and Pizzinato [48] is based on analyses of characteristics of archaeological sites and includes weights for archaeological features. The model first determines sensitivity of the area with respect to the presence and character of the site (uniqueness, age, rarity, level of conservation, and artistic level of the site) and defines in this way the hierarchy of significance of individual sites. The model then observes risks from environment and defines the total risk for individual sites, as well as interventions that are needed to protect the site.

The strategies model [49] was developed on the basis of the analysed models (pyramidal model in particular) and on the landscape analysis. The model uses the matrix approach adapted for the evaluation of heritage, and the final result is synthesized in cards that combine the matrix estimation, SWOT analysis, detailed indications for the use of heritage and evaluation of the "heritage value for money". The Table 3 shows an excerpt from the matrix for the evaluation of a cultural landscape. Matrices are organised according to heritage categories and evaluation themes (characteristics of context, cultural and historical features, etc.). After evaluation of the existing condition, the strategy for the use and renewal of heritage is defined, based on appropriate instructions. The scenario created in this way can be compared with scenarios created in relation to an objective, e.g. basic maintenance only, or with the scenario "do nothing".

The data needed for the use of various evaluation methods are obtained by analyzing characteristics of the space, landscape, and heritage (e.g. by morphological-historical analysis, by analyzing dynamics of urban development, by urban morphology analysis, etc.).

Architectural complexes can be analyzed by means of typologicalfunctional analyses, by analyzing the structure, layers, and construction phases, and by other approaches that enable us to understand features of an architectural complex. The historical approach uses written sources, historical drawings, pictures, graphical representations, sculptures, and photographs of the area under study. Graphical materials are especially helpful if they can be used for making comparison between historic and current condition.

The landscape analysis model developed by Giaoutzi and Frantzi [50] focuses on the structure of the landscape, and also on formal correlations between landscape elements (heights, barriers, microunits of space, colour, texture, social characteristics of space, etc.). Landscape analyses are highly complex because of landscape characteristics and various impacts of the project on abiotic, biotic, and human components - pollution, perception of change, influence on the connection between various parts of the ecosystem, etc. The following techniques are used in the analysis: system mapping, overlaying of thematic graphical presentations of data about natural and cultural components (e.g. risk areas, problematic development areas, natural and cultural areas, etc.). These analyses may be complemented by the use of GIS tools which relate spatial elements to characteristics contained in data bases. These data can also be expressed by means of Leopold matrices.

An important part of information can be obtained by analysis of visual influence using intervisibility maps or by simulating the change of perception over time.

The National park Service of the U.S. Department of the Interior [51] has developed its own model for the analysis and evaluation of local heritage and landscape. The analyses are made on the built and natural heritage, and the following aspects are considered: vegetation, animals, natural systems, use of areas, man-built water management infrastructure, vista points, buildings and other structures/facilities, gardens, fields, rural and urban areas, archaeological sites, demolished structures, and other elements (water tanks, irrigation elements, land enclosing elements, walkways, transport facilities). Elements are evaluated by means of qualitative ratings: contribute to the landscape identity, do not contribute to the landscape identity, support landscape identity, missing, belong to an non-determined period.

\section{Discussion}

According to literature data, some indicators are typical for evaluation of heritage. The extract of such indicators is given in Table 1. It can be seen that the indicators are related not only to cultural but also to social properties of heritage and, in case of landscape evaluation, the indicators include natural and artificial landscape elements, but also the living world.

The extract of characteristic economic and financial indicators [5256] is given in Table 2. It can be observed that financial indicators 
for the use of a heritage asset also partly differ from standard indicators, and include the cost of conservation, archaeological excavation, conservation of structures/facilities, sponsorship, lower tax burden for the maintained asset, and higher tax burden for buildings in the vicinity of an attractive heritage asset. The costs and benefits can be monitored through finances of the private or third sector that manage the area or use the heritage asset, and through finances of the public sector that can encourage, directly or indirectly, the desired use of the heritage asset, but also generate revenues in relation to the use of the heritage asset (e.g. through taxation).

Initial investment costs can be part of the negotiations on the distribution of costs, while management costs are mostly linked to the organization that manages a particular heritage asset. Direct costs are related to the private or third sector (revenues from the visitors, donations and sponsorships, etc.), while the public sector obtains a great part of income through indirect revenues (e.g. taxation), but also through concessions, ownership rights, and copyrights (research related to biodiversity, local products, etc.). The sustainability of heritage management can be expressed through indicators such as the number of products with the controlled origin, and also through quality of new workplaces. In order to generate real economic effects through the use of a heritage asset, it is precisely these segments that require negotiations and the decision-making procedure involving (local) general public and various social sectors.

Some of the analysed evaluation models are best suited for the first synthetic evaluation of space and heritage (such as the SWOT analysis, cobweb model, flag model, pyramidal model), while others are appropriate for synthetic analysis of detailed data (entrepreneur model, Kalman method, landscape analysis or archaeological impact model, hierarchical models). Basic features and intended use of some frequently used evaluation methods are synthetically presented in Table 3.

Although only some of the evaluation models have been developed specifically for heritage assessment (entrepreneur model, pyramidal model, Kalman method, landscape analysis, archaeological impact model, heritage value for money, strategies model), most other models can also be used for the evaluation of heritage if they are integrated with heritage analyses. The synthetic presentation of data is usually preceded by a detailed analysis of heritage using numerous specific analytical techniques. Some models are destined for a detailed evaluation of sustainability of a proposed plan or project (Environmental Impact Assessment, Strategic Evaluation of an environmental plan and program, nature impact assessment, Community Impact Evaluation, Heritage value for money, strategies model, GIS tools, etc.), while others are more appropriate for communication and presentation (SWOT analysis, cobweb model, flag model, pyramidal model, Kalman method, landscape analysis, Heritage value for money, strategies model, Community Impact Evaluation, etc.).

Community Impact Evaluation is the method specifically developed for expressing influence on different social sectors, although most other methods are also capable of expressing social sustainability.
Table 1. Typical indicators for the evaluation of the cultural built heritage [49]

\begin{tabular}{|c|c|}
\hline Source & Criterion \\
\hline $\begin{array}{l}\text { Fusco Girard } \\
\text { \& Nijkamp } \\
\text { (1997) }\end{array}$ & $\begin{array}{l}\text { - Location } \\
\text { - Artistic content } \\
\text { - Symbolic content } \\
\text { - Integration with surroundings } \\
\text { - Condition of structure/facility } \\
\text { - Inclusion in thematic contents } \\
\text { - Local identity } \\
\text { - Authenticity } \\
\text { - Exceptionality } \\
\text { - Psychological benefit } \\
\text { - Cultural diversity } \\
\text { - Diversity in use }\end{array}$ \\
\hline $\begin{array}{l}\text { Ashworth } \\
\text { \& Howard } \\
\text { (1999) }\end{array}$ & - Heritage user groups \\
\hline $\begin{array}{l}\text { Cecchini \& } \\
\text { Plaisant } \\
\text { (2005) }\end{array}$ & $\begin{array}{l}\text { - Participation of population } \\
\text { - Degraded areas } \\
\text { - Dysfunctional spaces } \\
\text { - Spatial fragmentation }\end{array}$ \\
\hline $\begin{array}{l}\text { Lichfield } \\
\text { (1988), } \\
\text { Kalman } \\
\text { method }\end{array}$ & $\begin{array}{l}\text { - Architecture - style, construction, age, architect, } \\
\text { design, interior } \\
\text { - History - people, event, context } \\
\text { - Environment - continuity, context, character of } \\
\text { monument } \\
\text { - Use - compatibility, adaptability, public services, } \\
\text { costs } \\
\text { - Integrity - aite alterations, condition }\end{array}$ \\
\hline $\begin{array}{l}\text { National } \\
\text { Park } \\
\text { Service U.S. } \\
\text { Department } \\
\text { of the } \\
\text { Interior, } \\
\text { The register } \\
\text { of national } \\
\text { landscape } \\
\text { monuments }\end{array}$ & $\begin{array}{l}\text { - Connection with events and persons of national } \\
\text { - Significance } \\
\text { - Embodiment of an idea or ideal for American } \\
\text { - Expulation } \\
\text { - } \text { a way of live or culture } \\
\text { - Remarkable features of a type, period, structural } \\
\text { methods, authors, artistic values } \\
\text { - Information of scientific significance } \\
\text { - Natural landscape elements: trees, wells, etc. } \\
\text { - Space - architecture, fields, orchards, gardens, } \\
\text { natural areas } \\
\text { - Intended use - residential, agricultural } \\
\text { - Elements of material culture and technology - } \\
\text { irrigation, fences } \\
\text { - Connecting routes - roads, walkways, paths } \\
\text { - Vista points } \\
\text { - Plant life } \\
\text { - Structures/facilities - agricultural elements, water } \\
\text { management elements, irrigation channels, ditches } \\
\text { - Smaller elements } \\
\text { - Archaeological sites, destroyed sites } \\
\text { - Animals }\end{array}$ \\
\hline $\begin{array}{l}\text { Canadian } \\
\text { national } \\
\text { parks }\end{array}$ & $\begin{array}{l}\text { - Association with historical theme, people/events, } \\
\text { local development, } \\
\text { - Architecture: aesthetic design (proportion, scale, } \\
\text { detail), functional design (materials, layout, method } \\
\text { of construction), crafts and materials, architect } \\
\text { (representation) } \\
\text { - Environment: site - integrity of relationship between } \\
\text { building and landscape, context - the influence on } \\
\text { the area of the building, monument - the nature of } \\
\text { the building in the community }\end{array}$ \\
\hline $\begin{array}{l}\text { Throsby } \\
\text { (2001) }\end{array}$ & $\begin{array}{l}\text { - Cultural value consisting of: } \\
\text { - Aesthetic values - beauty, harmony, form, style, } \\
\text { fashion, other } \\
\text { - Spiritual values - religious, universal, } \\
\text { understanding, openness, intuition } \\
\text { - Social values - relationship with others, } \\
\text { understanding nature of the society, sense of } \\
\text { identity } \\
\text { - Historic values - representation of the living } \\
\text { conditions of the historical period, sense of } \\
\text { continuity } \\
\text { - Symbolic values - carrier of significance } \\
\text { - Authenticity values - real, original and unique work }\end{array}$ \\
\hline
\end{tabular}


Table 2. Typical financial indicators for the evaluation of cultural built heritage ("+" - impact, "(+)" possible impact, [49, 52-56]

\begin{tabular}{|c|c|c|c|c|}
\hline \multicolumn{3}{|c|}{ Indicators of significant costs and benefits for the private and public sector } & \multirow{2}{*}{$\begin{array}{c}\begin{array}{c}\text { Private / } \\
\text { third sector }\end{array} \\
(+)\end{array}$} & \multirow{2}{*}{$\begin{array}{c}\text { Public sector } \\
+\end{array}$} \\
\hline \multirow{13}{*}{ 苞 } & \multirow{2}{*}{$\begin{array}{l}\text { Conservation and renewal of } \\
\text { built and natural heritage }\end{array}$} & Construction of infrastructure & & \\
\hline & & Environment improvement and landscape works & $(+)$ & + \\
\hline & \multirow{4}{*}{ Excavation costs } & Organisation and protection works & $(+)$ & + \\
\hline & & Excavation works & $(+)$ & + \\
\hline & & Conservation of finds & $(+)$ & $(+)$ \\
\hline & & Cost of transporting finds to specialized facilities & $(+)$ & + \\
\hline & \multirow{5}{*}{ Management costs } & Payments and contributions for employees and temporary employees & + & + \\
\hline & & Cost of regular life-long education & + & + \\
\hline & & General annual maintenance & + & \\
\hline & & Periodic maintenance and conservation (for a ten-year period) & + & \\
\hline & & Insurance costs & + & \\
\hline & \multirow{2}{*}{ Production costs } & Tax for location and heritage & + & \\
\hline & & Prospecting costs & + & + \\
\hline \multirow{15}{*}{ 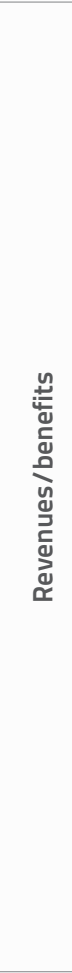 } & \multirow{4}{*}{ Earned revenues } & $\begin{array}{l}\text { Revenue from consumption in the area (overnight stays, } \\
\text { vacationers, local public and interest groups) }\end{array}$ & + & \\
\hline & & Expected consumption per visitor & + & \\
\hline & & Biodiversity prospecting & + & + \\
\hline & & Sale of products via commercial network and Internet & + & \\
\hline & \multirow{3}{*}{ Additional revenues } & $\begin{array}{l}\text { Donations from and outside of the area, by interest groups and } \\
\text { other groups }\end{array}$ & + & \\
\hline & & $\begin{array}{l}\text { Sponsorship by private organisations (banks, foundations, etc.), } \\
\text { international non-profit funds and public administration }\end{array}$ & + & \\
\hline & & International multilateral and bilateral funds & + & + \\
\hline & \multirow{8}{*}{ General revenues } & Exemption from property tax & + & \\
\hline & & Investment aids & + & \\
\hline & & Transfer of development rights & + & + \\
\hline & & Location and heritage tax & & + \\
\hline & & Rent and hotel accommodation tax & & + \\
\hline & & Biodiversity prospecting tax & & + \\
\hline & & $\begin{array}{l}\text { Higher tax revenues from consumption of energy and water } \\
\text { resources }\end{array}$ & & + \\
\hline & & Higher property tax & & + \\
\hline \multirow{7}{*}{\multicolumn{2}{|c|}{ Project sustainability indicators }} & Growth of capital assets & + & \\
\hline & & Financial and economic internal rate of return & + & \\
\hline & & Cost-benefit ratio or profitability index & + & \\
\hline & & New employments, age and gender characteristics & & + \\
\hline & & Employee income level & & + \\
\hline & & $\begin{array}{l}\text { Number of products with controlled origin or with registered } \\
\text { ownership }\end{array}$ & & + \\
\hline & & Relationship between $20 \%$ highest and $20 \%$ lowest income levels & & + \\
\hline
\end{tabular}


Table 3. Comparison of different evaluation methods, according to literature, extract. ("+" - characteristic of the method, "(+)" - possible use of the method, usually with planned precautions)

\begin{tabular}{|c|c|c|c|c|c|c|c|c|c|}
\hline Purpose of model & 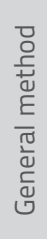 & 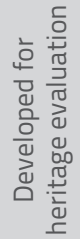 & 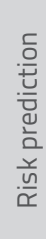 & 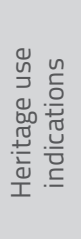 & 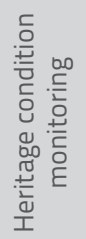 & 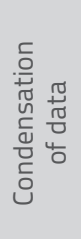 & 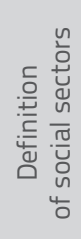 & 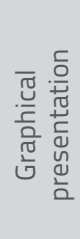 & 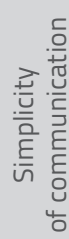 \\
\hline SWOT analysis & + & & + & & & + & $(+)$ & & + \\
\hline Cobweb model & + & & + & & + & + & $(+)$ & + & + \\
\hline Flag model & + & & $(+)$ & & + & + & $(+)$ & + & + \\
\hline Entrepreneur model & & + & + & + & & & & & \\
\hline Pyramidal model & & + & & + & + & + & & + & + \\
\hline Kalman method & & + & & & + & & & & + \\
\hline Landscape analysis & & + & + & & + & & & $(+)$ & + \\
\hline Archaeological impact model & & + & + & & & & & + & \\
\hline Heritage value for money & & + & & + & & + & & $(+)$ & + \\
\hline Strategies model & & + & + & + & + & & & & + \\
\hline Environmental impact assessment & + & & + & & $(+)$ & & $(+)$ & $(+)$ & \\
\hline Nature impact assessment & + & & + & & $(+)$ & & & $(+)$ & \\
\hline $\begin{array}{l}\text { Strategic evaluation of the impact of plan and program on } \\
\text { the environment }\end{array}$ & + & & + & & $(+)$ & & $(+)$ & $(+)$ & \\
\hline Community Impact Evaluation & + & & + & & & + & + & & + \\
\hline Hierarchy determination methods & + & $(+)$ & & & & + & & & \\
\hline GIS tools (in combination with matrix or other models) & + & & + & $(+)$ & + & + & & + & \\
\hline
\end{tabular}

A number of evaluation methods can be used for heritage monitoring (e.g. Kalman's method, strategies model, GIS tools, Canadian national parks method, cobweb model, flag model, pyramidal model, landscape analysis). Some methods enable risk prediction (archaeological impact model, SWOT analysis, cobweb model, pyramidal model, landscape analysis, strategies model, Community Impact Evaluation, GIS tools), and some point to desirable heritage interventions aimed at ensuring sustainable development and use of heritage (entrepreneur model, pyramidal model, Heritage value for money, strategies model, etc.). The strategies model can be used in different segments of the decision-making process (analysis, scenarios development, impact assessment), but only for the processes relating to the use of heritage.

\section{Conclusion}

The use and protection of the existing natural and cultural heritage provides an opportunity for the start of a sustainable development process based on the distinctive features of an area, taking into account the need to limit negative influences on human and natural systems.

Cultural heritage is the carrier of cultural and economic values. Although financial values can be evaluated through financial analyses, cultural values can be estimated by multicriteria analyses, which include the use value of the heritage, and the intrinsic value of the heritage.

The integration of heritage preservation in spatial planning processes opens the path toward establishment of an appropriate connection between social, environmental, economic and cultural aspects of sustainability. Spaces or locations in which the presence of cultural heritage is notable can be regarded as multi-layered spaces where cultural, environmental, institutional and social layers merge.

In such complex systems, the planning activity calls for the use of appropriate tools that enable existing condition analysis, as well as the diagnosis, presentation, definition and evaluation of development scenarios. These tools must be able to analyse the complexity, fragmentation and multi-layered nature of correlations between material and nonmaterial elements of the space, and to examine uncertainties with regard to preservation of historic values and their replacement.

Various heritage evaluation methods have been developed since the mid-twentieth century. Some are based on financial values, and others on the multicriteria approach which connects qualitative and quantitative evaluations of space and heritage. It can be concluded that the best results are obtained by combination of different types of evaluations, depending on the decision-making phase, availability of data, and objectives to be achieved. For instance, combined methods involving 
Environmental Impact Assessment, Kalman method, and Community Impact Evaluation method, can be used for predicting impact and communication with stakeholders and the general public. The Kalman method can be used for architectural heritage monitoring. Canadian national park models, strategies models etc. - combined when possible with GIS tools - can be used for landscape evaluation and monitoring, while the pyramidal model, entrepreneur model, Heritage value for money, or strategies model, can be used for the diagnosis and establishment of scenarios.

\section{REFERENCES}

[1] Values and Heritage Conservation, Research Report, Los Angeles, eds. E. Avrami, R. Mason, M. de la Torre, The Getty Conservation Institute, Los Angeles, 2000. http://www.getty. edu/conservation/publications_resources/pdf_publications/ pdf/valuesrpt.pdf, 2013.

[2] Throsby, D.: Economics and Culture, Cambridge University Press, Cambridge, 2001.

[3] Economics and Heritage Conservation: Concepts, Values, and Agendas for Research, in Economics and Heritage Conservation, A Meeting Organized by the Getty Conservation Institute, December 1998, Los Angeles, ed. R. Mason, Getty Conservation Institute, Los Angeles, CA, 1998. http://www.getty.edu/ conservation/publications_resources/pdf_publications/pdf/ econrpt.pdf, 2013.

[4] Greffe, X.: La gestione del patrimonio culturale, FrancoAngeli, Milano, 2003.

[5] Greffe, X.: Cultura e sviluppo locale, OECD, Provincia Autonoma di Trento, Nicolodi, Trento, 2005.

[6] Fusco Girard, L.: Multidimensional evaluation process to manage creative, resilient and sustainable city, Aestimum, 59, pp. 123-139, 2011.

[7] Occelli, S.: Le metodologie come impegno all'azione: il ruolo dell'attività modellistica (Chapter), Analisi e modelli per la pianificazione. Teoria e pratica: lo stato dell'arte, eds. A. Cecchini \& A. Plaisant, FrancoAngeli, Milano, pp.72-83, 2005.

[8] La valutazione ambientale strategica e la nuova Direttiva comunitaria, eds. A. Busca \& G. Campeol, Palombi Editori, Rim, 2002.

[9] Coote, A., Lenaghan, J.: Citizens' Juries: Theory Into Practice, Institute for Public Policy Research, London, 1997.

[10] Landry, Ch.: The Creative City. A Toolkit For Urban Innovators, Eartscan Publications, London, 2000.

[11] Riqualificare la città con gli abitanti, eds. A. De Eccher, E. Marchigiani, E. Marin, EdicomEdizioni, Monfalcone, 2005.

[12] Mela, A., Belloni, M.C., Davico, L.: Sociologia e progettazione del territorio, Carocci editore, Roma, 2000

[13] Archibugi, F.: La valutazione dell'utiltià sociale di programmi e progetti: alcune considerazioni preliminari e metodologiche, Sviluppo economico, 2-3, pp. 113-158, 1999.

[14] Voogd, H.: La valutazione nella pianificazione dello sviluppo regionale: alcune osservazioni metodologche, Sviluppo economico, 2-3, pp. 41-62, 1999.

[15] Le valutazioni per lo sviluppo sostenibile della città e del territorio, eds. L. Fusco Girard \& P. Nijkamp, FrancoAngeli, Milano, 1997.

[16] Cecchini, A.: La scatola di attrezzi (Chapter), Analisi e modelli per la pianificazione. Teoria e pratica: lo stato dell'arte, eds. A. Cecchini \& A. Plaisant, FrancoAngeli, Milano, pp.18-28, 2005.
[17] Pickard R., de Thyse, M.: The management of historic centres: towards a common goal (Chapter), Management of Historic Centres, eds. R. Pickard, Spoon Press, London, pp.274-290, 2001.

[18] Lowenthal, D.: Stewarding the Past in a Perplexing Present (Chapter), Values and Heritage Conservation, Research Report, Los Angeles, eds. E. Avrami, R. Mason, M. de la Torre, The Getty Conservation Institute, Los Angeles, pp.18-25, 2000. <http:// www.getty.edu/conservation/publications_resources/pdf_ publications/pdf/valuesrpt.pdf>, 2013.

[19] Fusco Girard, L., Nijkamp, P.: I metodi di valutazione (Chapter), Le valutazioni per lo sviluppo sostenibile della città e del territorio, eds. L. Fusco Girard \& P. Nijkamp, FrancoAngeli, Milano, pp.141179, 1997

[20] Carta, M.: L'armatura culturale del territorio. II patrimonio culturale come matrice di identità e strumento di sviluppo, FrancoAngeli, Milano, 2002.

[21] Rappresentare i luoghi. Metodi e tecniche, ed. A. Magnaghi, Alinea Editrice, Firenze, 2001.

[22] Vaz, E., Nijkamp, P.: Historico-Cultural Sustainability and Urban Dynamics - A geo-information Science Approach to the Algarve Area, Serie Research Memoranda, VU University Amsterdam, 21, pp.1-25, 2009.

[23] Harvey, D. C.: Heritage Pasts and Heritage Presents: temporality, meaning and scope of heritage studies, International Journal of Heritage Studies, Vol. 7, 4, pp.319-338, 2001.

[24] Cecchini, G., Pagano, M.: Alcune considerazioni e prospettive sul ruolo della pianifiazione territoriale per a valutazione strutturale e strategica in un processo partecipativo e di sussidiarietà per i servizi d'area vasta nel Ptcp (Chapter), Analisi e modelli per la pianificazione. Teoria e pratica: lo stato dell'arte, eds. A. Cecchini \& A. Plaisant, FrancoAngeli, Milano, pp.84, CD, 2005.

[25] Mazzanti, M.: Metodi e strumenti di analizi per la valutazione economica del patrimonio culturale, FrancoAngeli, Milano, 2003.

[26] Mossetto, G. \& Vecco, M.: Economia del patrimonio monumentale, FrancoAngeli, Milano, 2001.

[27] Navrud, S., Ready, R. C.: Valuing Cultural Heritage. Applying Environmental Valuation Techniques to Historic Buildings, Monuments and Artifacts, Edward Elgar Publishing, Cheltenham, 2002.

[28] Armaly, M. J., Pagiola, S.P., Bertaud, A.: Economics of Investing in Heritage: Histoic Center of Split (Chapter), Historic Cities and Sacred Sites. Cultural Roots for Urban Futures, eds. I. Serageldin, E. Shluger, J. Martin-Brown, The International Bank for Reconstruction and Development, The World Bank, Washington D.C., pp.165-179, 2001. 
[29] Tirendi, D.: Valutazione di contingenza nei progetti di riqualificazione urbana. Analisi dell'applicazione dello strumento valutativo nell'ambito della valorizzazione di centri storici: i casi della Medina di Fes (Marocco) e di Spalato (Croazia), Estimo e Territorio, br. 4, pp.8-12, 2005.

[30] Planning for Our Cultural Heritage, eds. H. Coccossis \& P. Nijkamp, Ashgate Publishing Limited, Avebury, 1995.

[31] Mossetto, G.: L'economia delle città d'arte. Modelli di sviluppo a confronto, politiche e strumenti di intervento, EtasLibri, Milano, 1992.

[32] Frey, B., Oberholzer-Gee, F.: Public Choice, Cost-Benefit Analysis, and the Evaluation of Cultural Heritage (Chapter), Does The Past Have a Future?, ed. A. Sir Peacock, The Institute of Economic Affairs, London, pp.27-53, 1998.

[33] Chadwick G.: A Systems View of Planning, Towards a Theory of the Urban and Regional Planning Process, Pergamon Press, Oxford, 1981.

[34] Zeleny, M.: Multiple criteria decision making, McGraw-Hill Book New York, 1982

[35] Keeney, R. L.: Value-Focused Thinking. A Path to Creative Decisionmaking, Harvard University Press, Cambridge, MA, 1992.

[36] Leopold L. B., Clarke, F.E., Hanshaw, B.B., Balsley, J.R.: A Procedure for Evaluating Environmental Impact, United States Department of the Interior, Washington, Geological Survey 1971, Circular n. 645, 1971. http://eps.berkeley.edu/ people/lunaleopold $/ \% 28118 \% 29 \% 20$ A 20 Procedure $\% 2$ for $\% 20$ Evaluating\%20Environmental\%20lmpact.pdf (srpanj 2013.)

[37] De Bonis, L: Valutazione ambientale e partecipazione (Chapter), Metodi e procedure di partecipazione e alle scelte urbanistiche, eds. G. Castelli, Aracne, Rim, pp.173-178, 2005.

[38] Lichfield, N.: Economics in Urban Conservation, Cambridge University Press, Cambridge, 1988.

[39] Nijkamp, P., Bal, F., Medda, F.: A survey of methods for sustainable city planning and cultural heritage management, Free University of Amsterdam, Amsterdam, 1998.

[40] Nijkamp, P., Medda, F.: Integrated Assessment of Urban Revitalization Projects (Vhapter), The human sustinable city: challenges and perspectives from the Habitat Agenda, eds. L. Fusco Girard, B. Forte, M. Cerreta, M., P. De Toro, F. Forte, Ashgate Publishing, Aldershot, UK, Burlington, USA, pp.417-428, 2003.

[41] Berger, P. L., Luckmann, T.: The Social Construction of Reality, Doubleday and Co., Garden City, New York, 1966.

[42] Cellamare, C.: Culture e progetto del territorio, FrancoAngeli, Milano, 1997

[43] Ashworth, G. J., Howard, P.: Dimensions and scope of heritage, European Heritage Planning and Management, eds. G.J. Ashworth, P. Howard, Intellect, Exeter, 1999.
[44] Kalman, H.: The Evaluation of Historic Buildings, Parks Canada, Ottawa, Canada, 1979.

[45] Pypaert, P., Carollo, S.: Valutazione ambientale e sviluppo sostenibile: il caso di Omišalj in Croazia, Rim, 2001. http:// host83-40-static.86-94-b.business.telecomitalia.it/export/ sites/default/archivio/allegati/vari/vas_seminario_pypaert_ carollo.pdf, 2013.

[46] Mongiello, M., Vecco, M.: Aspetti gestionali di un progetto di riutilizzo. La Scuola Grande della Misericordia (Chapter), Economia del patrimonio monumentale, G. Mossetto \& M. Vecco, FrancoAngeli, Milano, pp.101-124,175-192, 2001.

[47] Kanadski nacionalni parkovi: Parks Canada http://www.pc.gc. ca/eng/index.aspx, srpanj 2013.

[48] Campeol, G., Pizzinato, C.: Metodologia per la valutazione dell'impatto archeologico, Archeologia e Calcolatori, 18, pp. 273292, 2007.

[49] Mrak, I.: Multicriteria evaluation for cultural heritage management from a sustainable spatial development perspective, doktorska dizertacija, University of Nova Gorica Graduate School, Venice, Nova Gorica, 2011.

[50] Giaoutzi, M. \& Frantzi, M.: Svilupo sostenibile e valutazione del paesaggio (Chapter), Le valutazioni per lo sviluppo sostenibile della città e del territorio, eds. L. Fusco Girard \& P. Nijkamp, FrancoAngeli, Milano, pp.259-287, 1997.

[51] National Park Service U.S. Department of the Interior, http:// www.nps.gov/grko/parkmgmt/planning.htm, srpanj 2013.

[52] Financial appraisal for heritage projects, Heritage lottery fund, 2008. http://www.hlf.org.uk/preApril2013/furtherresources/ Documents/03_HLF_FAHP.pdf, 2013.

[53] Long-term Financial Planning for Parks and Protected Areas, The Nature Conservancy, Arlington, Virginia, USA, 2001. https:/ / www.cbd.int/doc/nbsap/finance/TNC-FinPlanGuide2001_ english.pdf, srpanj 2013.

[54] A Framework for Indicators for the Economic and Social Dimensions of Sustainable Agriculture and Rural Development, European Commission Agriculture Directorate-General, 2001. http://ec.europa.eu/agriculture/publi/reports/sustain/index_ en.pdf, srpanj 2013.

[55] Local Government Financial Indicators, Local government Association of South Australia, 2006, Information Paper 9, November 2006, LGA Financial Sustainability Program, 2006. http://www.lga.sa.gov.au/webdata/resources/files/ Financial_Sustainability_Info_Paper_9_-_Local_Government_ Financial_Indicators.pdf, srpanj 2013.

[56] La valutazione dei progetti d'investimento pubblici. Linee guida. Quaderni del NUVV - 1, Regione del Veneto, Giunta regionale Venezia, Centro di ricerca Interuniversitario sull'Economia Pubblica, http://db.formez.it/fontinor.nsf/0/3F19CC354F39 F400C1257298003477FC/\$file/La\%20valutazione\%20dei\%20 progetti\%20degli\%20investimenti\%20pubblici.pdf, srpanj 2013. 